\title{
KARAKTERISTIK DAN PERSEPSI WISATAWAN DI DESTINASI WISATA TANAH LOT (Studi Pemetaan Sosial - Budaya)
}

\author{
Syul Rosli Sanam \\ Email: syul.rosli@ pib.ac.id \\ POLITEKNIK INTERNASIONAL BALI
}

\begin{abstract}
Tanah Lot is one of the leading tourism destinations which is in natural and cultural potential unique and interesting, to attract, both domestic and foreigners to make them visits to this tourist destination. With the increasing number of tourist arrivals to Tanah Lot, it has contributed significantly to the manager, as well as improved the welfare of local communities. In order to know the market segment of tourists visiting Tanah Lot, it is necessary to do a social-cultural mapping, to know the characteristics and perception of tourists about the condition and existence of Tanah Lot. This it should be proposed in maintaining the stages of development of Tanah Lot tourist destination as described by Destination Life Cycle. Demand and product offerings are an important thing that local people need to provide to tourists, so the satisfaction of the service can give a good image in the minds of the tourists.
\end{abstract}

Keywords: Characteristics and Perceptions, Tourism Destination, Social Cultural Mapping

\begin{abstract}
Abstrak
Tanah Lot adalah salah satu tujuan wisata terkemuka yang kaya akan potensi alam dan budaya yang unik dan menarik, sehingga mampu menarik wisatawan, baik wisatawan domestik maupun mancanegara untuk melakukan kunjungan wisata ke tujuan wisata ini. Dengan semakin banyaknya kedatangan wisatawan ke Tanah Lot telah memberikan kontribusi signifikan kepada pengelola, sehingga dapat meningkatkan kesejahteraan masyarakat setempat. Untuk mengetahui segmen pasar wisatawan yang berkunjung ke Tanah Lot, perlu dilakukan pemetaan sosial budaya, yaitu untuk mengetahui karakteristik dan persepsi wisatawan tentang kondisi dan keberadaan Tanah Lot, sehingga harus diusulkan dalam mempertahankan tahapannya. pengembangan tujuan wisata Tanah Lot yang dijelaskan oleh Tujuan Life Cycle. Permintaan dan penawaran produk adalah hal penting yang perlu diberikan oleh penduduk setempat kepada wisatawan, sehingga kepuasan layanan dapat memberikan citra yang baik di benak para wisatawan.
\end{abstract}

Kata Kunci: Karakteristik dan Persepsi, Tujuan Wisata, Pemetaan Budaya Sosial 


\section{Pendahuluan}

Tanah Lot merupakan salah satu Destinasi Wisata (DTW) unggulan yang ramai dikunjungi wisatawan domestik dan internasional. Dengan panorama alam yang indah dan keunikan atraksi budaya yang dimiliki, Tanah Lot telah dikelola secara professional dilengkapi dengan fasilitas parkir, public toilet, art shop, restoran, hotel, open stage, tourist information centre, security dan safety. Pemandangan khas laut selatan dengan ombak yang bisa disaksikan dari ketinggian tebing di atas 15 meter merupakan atraksi alam yang sangat mempesona dan mampu menahan para pengunjung agar tinggal lebih lama serta termotivasi untuk kembali berkunjung menyaksikan keindahan alam dan keunikan atraksi budaya.

Saat ini Tanah Lot menjadi salah satu DTW yang mengalami peningkatan dalam jumlah kunjungan wisatawan. Hal ini terjadi karena potensi dan daya tarik wisata yang dimiliki Tanah Lot sudah dikembangkan sesuai standar dengan berbagai produk wisata yang tersedia sehingga kepuasan akan kebutuhan dan keinginan wisatawan yang berkunjung ke Tanah Lot tercapai. Untuk mengetahui jumlah kunjungan wisatawan ke DTW Tanah Lot dalam kurun waktu lima (5) tahun terakhir dapat dilihat pada Tabel 1 berikut.

Data dari Manajemen Operasional DWT Tanah Lot jumlah Kunjungan wisatawan ke destinasi wisata Tanah Lot Tahun 2007 dari mancanegara sejumlah 517.926 orang dan domestic 779.571, tahun 2008 dari mancanegara sejumlah 620.440 dan domestic 954.368, tahun 2009 dari mancanegara sejumlah 725.665 dan domestic 1.128.355, tahun 2010 dari mancanegara sejumlah 793.330 dan domestic 1.356.563, tahun 2011 dari mancanegara sejumlah 872.876 dan domestic 1.443.090. Total kunjungan dari tahun 2007 sampai 2011 adalah 9.192.364. 
Tabel 1 menunjukkan bahwa angka jumlah kunjungan wisatawan dari tahun ke tahun mengalami fruktuasi. Dari tahun 2013 wisatawan yang berkunjung ke Tanah Lot berjumlah 3.145.244 pengunjung dengan tingkat pertumbuhan 19\%. Walaupun pada tahun 2014 jumlah kunjungan wisatawan mengalami penurunan namun tidak mempengaruhi tingkat persentase yakni 19\%. Pada Tahun 2016 tingkat kunjungan wisatawan mencapai 3.524.385 pengunjung dengan persentase 22\%. Sementara Tahun 2017 ini jumlah kunjungan ke Tanah Lot sebanyak 3.497.825 pengunjung. Jumlah tersebut turun sekitar $0,78 \%$ dibandingkan jumlah kunjungan tahun 2016 sebesar 3.525.335 pengunjung.

Hal tersebut diungkapkan Manajer Operasional Destinasi Wisata Tanah Lot, I Ketut Toya Adnyanan, Senin (1/1). Menurut Toya Adnyana, dibanding tahun sebelumnya jumlah kunjungan wisatawan ke Tanah Lot tahun 2017 ini mengalami penurunan sekitar 0,78 persen. Hal tersebut karena pengaruh dari erupsi Gunung Agung di Karangasem. Dampak dari Erupsi Gunung Agung tersebut sangat berpengaruh terhadap kunjungan wisatawan ke Destinasi Wisata Tanah Lot, dan disertai dengan penutupan Bandara Ngurah Rai. Penutupan Bandara Ngurah Rai dampaknya terasa signifikan terhadap penurunan kunjungan wisatawan ke Tanah Lot. Secara persentase, penurunan kunjungan wisatawan tahun 2017 sebesar 0,78 persen sesungguhnya relatif kecil namun secara kuantitas jumlahnya mencapai ribuan orang yaitu 27.510 orang wisatawan.

(Sumber: http://balitribune.co.id/content/kunjungan-wisatawan-di-tanahlot-2017-menurun-078-persen - akses: Senin, 01 Oktober 2018).

Berdasarkan uraian latar belakang, perlu mengetahui karakteristik dan persepsi wisatawan yang berkunjung ke DTW Tanah Lot. Hal ini bertujuan untuk mengetahui permintaan pariwisata yang dibutuhkan dan diinginkan oleh wisatawan dalam memenuhi tuntutan pasar, dan untuk mengatasi berbagai permasalahan sosial budaya yang terjadi di DTW 
Tanah Lot agar tetap menjadi DTW unggulan dalam menjaga dan melindungi sumber daya pariwisata yang dimiliki.

\section{Konsep Karakteristik dan Persepsi Wisatawan}

Karakteristik wisatawan yang dibahas pada artikel ini, meliputi: (1) Karakteristik Sosio-Demografis, seperti jenis kelamin, umur, status perkawinan, tingkat pendidikan, pekerjaan, ukuran keluarga atau jumlah anggota keluarga, dan lain-lain yang dielaborasi dari karakteristik tersebut. (2) Karakteristik Geografis, membagi wisatawan berdasarkan lokasi tempat tinggal. Dalam penelitian ini difokuskan pada negara asal wisatawan. (3) Karakteristik Psikografis, membagi wisatawan ke dalam kelompok-kelompok berdasarkan motivasi melakukan perjalanan wisata, beragamnya keinginan dan kebutuhan mereka akan suatu produk wisata (Kotler, 1996 dalam Suwena dan Widyatmaja, 2009: 41).

Dalam konteks sosiologis, perubahan persepsi dan motivasi wisatawan dalam melakukan perjalanan wisata terus mengalami perubahan. Menurut Plog (dalam Pitana, 2005), wisatawan dikelompokkan berdasarkan tipologi wisatawan, yaitu: 1) Allocentris, yakni wisatawan yang hanya ingin mengunjungi tempat-tempat yang belum diketahui, bersifat petualangan, dan besedia memanfaatkan fasilitas yang disediakan oleh masyarakat lokal; 2) Psychocentris, yakni wisatawan yang hanya ingin mengunjungi DTW yang sudah memiliki fasilitas yang sama dengan di negaranya; 3) Midcentris, yakni tipe wisatawan terletak di antara tipologi allocentris dan psychocentris. Persepsi wisatawan yang dimaksud adalah suatu aktivitas individu untuk mengenal suatu objek melalui alat inderanya yang kemudian dicerna, sehingga individu dapat memberikan tanggapan terhadap objek tersebut dengan sadar.

Ada beberapa pengertian persepsi. Menurut (Koentjaraningrat, 1980:105), menyebutkan bahwa: "Persepsi merupakan proses fisik dan 
psikologis yang menyebabkan berbagai macam getaran dan tekanan yang diolah menjadi suatu susunan yang dipancarkan atau diproyeksi oleh individu menjadi suatu penggambaran tentang lingkungan dengan fokus yang paling menarik perhatian seorang individu”. Sedangkan Walgito (1990:54), memberikan batasan bahwa persepsi adalah suatu kesan terhadap suatu obyek yang diperoleh melalui proses penginderaan, pengorganisasian, dan interpretasi terhadap obyek tersebut yang diterima oleh individu, sehingga merupakan suatu yang berarti dan merupakan aktivitas integrated dalam diri individu.

Menurut Hasanudin (2007) dalam konsep dasar pemetaan, mendefinisikan: Peta sebagai representasi gratis dari dunia nyata (real world) dari suatu ruang (space), sedangkan Pemetaan adalah proses kegiatan untuk mengasilkan suatu peta. Sosial merupakan rangkaian norma, moral, nilai, dan aturan yang bersumber dari kebudayaan suatu masyarakat atau komuniti yang digunakan sebagai acuan dalam berhubungan antar manusia. Pemetaan sosial pada dasarnya adalah usaha untuk menggambarkan, mendeskripsikan, mengidentifikasikan normanorma, moral, nilai dan aturan yang digunakan oleh manusia sebagai anggota masyarakat untuk mengatur hubungan interaksi yang terjadi didalamnya.

\section{Teori Siklus Hidup Destinasi Pariwisata}

Untuk memahami evolusi dari produk dan destinasi pariwisata yang ada di Tanah Lot, menggunakan siklus hidup destinasi yang dikemukakan oleh Butler (1980). Dalam perkembangan pariwisata, sangat dipengaruhi oleh perjalanan wisata yang dilakukan wisatawan dari Tourist Generating Area ke Tourist Destination Area. Tahapan pengembangan pariwisata merupakan siklus hidup yang terjadi dalam pembangunan pariwisata, mulai dari suatu DTW baru ditemukan (disconery), kemudian 
berkembang dan pada akhirnya terjadi penurunan (decline). Butler (1980 dalam Sukarsa 1999), mengungkapkan bahwa terdapat enam tingkatan atau tahapan dalam pembangunan pariwisata. Ke-enam tahapan tersebut adalah: 1) Exploration (Explorasi/Pertumbuhan Spontan dan Penjajakan). 2) Involvement (Keterlibatan). 3) Development (Pengembangan dan Pembangunan). 4) Consolidation (Konsolidasi dan Interelasi). 5) Stagnation (Kestabilan). 6) Decline (Penurunan Kualitas) atau Rejuvenation (Kelahiran Baru).

Gambar 1 Destination Life Cycle

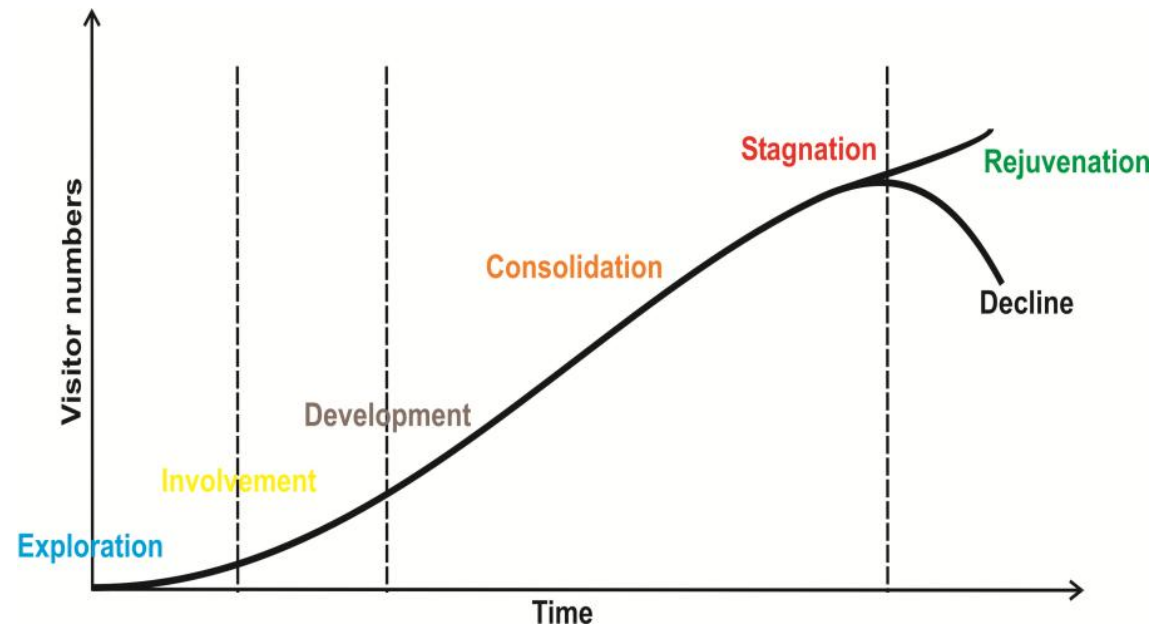

Sumber: Butler dalam Cooper and Jackson (1997)

Berdasarkan tahapan siklus hidup daerah pariwisata, yang tertera pada Gambar 1 di atas, jika dikaitkan dengan perkembangan DTW di Tanah Lot dapat diketahui bahwa dengan jumlah kunjungan wisatawan yang signifikan maka saat ini Tanah Lot berada pada tahapan ke 5 (lima), yaitu tahap Stagnation (Kestabilan). Pada tahap ini ditandai dengan tercapainya titik tertinggi dalam jumlah kunjungan wisatawan. Normalnya tahapan ini merupakan tahap terlama dalam siklus hidup produk destinasi wisata. Pada tahap ini pula, pemenuhan inti akan kebutuhan DTW yang bersangkutan tetap ada. Sebagian besar produk yang ada berada di 
destinasi tersebut berada pada tahap ini, karena itu sebagian besar pemasaran ditujukan untuk produk dalam tahap ini. Berbagai terobosan dilakukan oleh pelaku pariwisata serta adanya diversifikasi dan komodifikasi fasilitas, serta strategi pemasaran yang digunakan untuk memperpanjang daur hidup DTW.

\section{Karakteristik Wisatawan}

Data yang diperoleh dalam penelitian ini dilakukan dengan metode survei, yakni menyebar 250 kuesioner kepada wisatawan yang sedang berkunjung ke DTW Tanah Lot, yakni Wisatawan mancanegara maupun domestik. Berikut gambaran karakteristik wisatawan yang menjadi responden dalam penelitian.

\subsection{Berdasarkan Jenis Kelamin}

Wisatawan domestik dan mancanegara yang berkunjung ke Tanah Lot mayoritas berjenis kelamin laki-laki yakni 134 orang (54\%), sedangkan untuk wisatawan perempuan berjumlah 116 orang (116\%). Dalam melakukan aktivitas wisata memang seseorang harus banyak meluangkan waktu. Secara faktual, sebagian besar laki-laki lebih mudah melakukan perjalanan wisata. Sementara, perempuan memang lebih banyak memerlukan waktu untuk mempertimbangkan keputusannya. Berdasarkan jenis kelamin, terlihat perbedaan antara laki-laki dan perempuan, laki-laki tidak banyak berpikir tentang keadaan yang terjadi saat berwisata, namun perempuan biasanya lebih terencana, seluruh aktifitasnya harus direncanakan secara detial.

\subsection{Berdasarkan Umur}

Wisatawan dengan tingkat umur antara 15-24 tahun merupakan yang paling banyak berkunjung ke Tanah Lot yaitu sebanyak 133 orang (53\%). Pada usia ini sebagian besar yang mengunjungi Tanah Lot adalah para pelajar yang melakukan study tour dari berbagai daerah. Selain itu, 
wisatawan yang berumur 26-35 tahun sebanyak 49 orang (20\%). Hal ini disebabkan pada usia-usia seperti ini banyak yang sudah memiliki modal atau memiliki penghasilan sehingga mempermudah dalam melakukan perjalanan wisata. Wisatawan yang pada usia ke 36-45 tahun sebanyak 37 orang $(15 \%)$ dan usia 46 ke atas berjumlah 31 orang (12\%) pada usia-usia seperti ini mereka melakukan kunjungan berdasarkan keinginan masingmasing, dilihat dari faktor jarak dan waktu tempuh yang jauh menuju DTW Tanah Lot sehingga dituntut untuk mempersiapkan stamina yang prima.

\subsection{Berdasarkan Tingkat Pendidikan}

Mayoritas wisatawan yang berkunjung ke Tanah Lot berpendidikan SMA/SMK dengan jumlah 103 orang (41\%) dan Universitas (Sarjana) sebanyak 89 orang (36\%). Tingkat pendidikan merupakan salah satu unsur yang menggerakkan minat seseorang untuk berwisata. Dengan mengetahui tingkat pendidikan wisatawan ke Tanah Lot dapat mengetahui segmen pasar wisatawan berdasarkan level pendidikan.

\subsection{Berdasarkan Pekerjaan}

Latar belakang wisatawan berdasarkan pekerjaan digunakan untuk mengetahui apakah Tanah Lot dapat menarik minat wisatawan dari berbagai lapisan pekerjaan. Dengan memiliki pekerjaan yang layak memungkinkan seseorang dapat menyisihkan pendapatannya untuk melakukan kegiatan yang terlepas dari kejenuhan rutinitas sehari-hari. Dominan wisatawan yang berkunjung ke Tanah Lot berdasarkan pekerjaannya adalah pelajar, baik dari tingkat SMP, SMA/SMK, maupun Perguruan Tinggi atau mahasiswa yang berjumlah 85 orang (34\%), sebagai wiraswasta berjumlah 64 orang (26\%), pekerja biasa sebanyak 48 orang (19\%), dan pengangguran sebanyak 22 orang (9\%), dan wisatawan yang

paling sedikit berkunjung adalah ibu rumah tangga yang berjumlah 7 orang (3\%). Dengan mahalnya biaya perjalanan khusus untuk transportasi dan 
jarak tempuh yang jauh menyebabkan wisatawan harus mengalokasikan waktu dan anggaran perjalanan yang cukup agar memudahkan wisatawan dalam melakukan kunjungan wisata.

\subsection{Berdasarkan Asal Wisatawan}

Adapun tujuan mengkomposisi wisatawan berdasarkan daerah asal yakni, untuk mengetahui wisatawan dari daerah manakah yang mendominasi dalam mengunjungi destinasi wisata Tanah Lot. Wisatawan yang berkunjung ke Tanah Lot ada tipe wisatawan yaitu wisatawan lokal yakni yang berasal dari daerah Bali, wisatawan domestik yakni wisatawan yang berasal dari luar daerah/ provinsi lain, dan wisatawan macanegara yakni wisatawan yang berasal dari negara lain. Dapat dilihat bahwa wisatawan yang mendominasi dalam berkunjung ke destinasi wisata Tanah Lot adalah wisatawan domestik yaitu sebanyak 145 orang (58\%). Sedangkan wisatawan mancanegara sebanyak 105 orang $(42 \%)$.

Jika dilihat wisatawan mancanegara yang berasal dari Benua Eropa menempati jumlah kunjungan terbanyak dibandingkan wisatawan dari kawasan lain di dunia, yaitu sebanyak 44 orang (18\%). Hal ini berkaitan dengan karakteristik dari wisatawan Eropa yang umumnya menyukai daya tarik wisata alam, bersifat petualang, dan cenderung menerima penyediaan fasilitas yang terdapat di DTW. Sedangkan wisatawan dari Australia sebanyak 21 orang (8\%), hal ini disebabkan karakteristiknya yang hampir sama dengan wisatawan asal Eropa yakni, menyukai kegiatan wisata alam.

\subsection{Berdasarkan Frekuensi Kunjungan}

Keinginan wisatawan untuk mengunjungi Tanah Lot dilatar belakangi dengan berbagai dasar dan pertimbangan untuk memperoleh kepuasan. Dengan demikian, tidak heran apabila suatu daya tarik wisata dikunjungi oleh wisatawan yang sama berulang kali. Hal ini terjadi karena daya tarik yang dimiliki sangat unik dan menarik, serta pelayanan yang 
diberikan sangat memuaskan sehingga menimbulkan kesan yang istimewa bagi para pengunjungnya. Mayoritas wisatawan yang berkunjung antara 12 kali ke Tanah Lot adalah sebanyak 145 orang (58\%). Sedangkan wisatawan yang sudah berulang kali berkujung lebih dari 5 kali sebanyak 57 orang (23\%). Dan wisatawan yang berkunjung antara 3-4 kali sebanyak 48 orang (19\%). Salah satu kendala yang menyebabkan minimnya periode kunjungan adalah jarak dan waktu yang dibutuhkan untuk menjangkau Tanah Lot, namun sebagian besar wisatawan memiliki minat untuk kembali melakukan kunjungan ke Tanah Lot.

\section{Persepsi Wisatawan}

Untuk menganalisis data yang dikumpulkan melalui penyebaran kuesioner pada 250 responden, maka dibuat kategori persepsi wisatawan dengan menggunakan metode pengukuran sikap (skala rikert).

\subsection{Pemandangan Alam Di Tanah Lot}

Pemandangan alam yang indah menjadi salah satu alasan bagi wisatawan untuk berkunjung ke tempat wisata tersebut. Pemandangan alam yang dimiliki Tanah Lot dijadikan sebagai salah satu daya tarik bagi wisatawan untuk berkunjung. Pemandangan alam yang ada di Tanah Lot sangat menarik minat wisatawan sehingga wisatawan seringkali merasa ketagihan akan keindahan alam yang dimiliki Tanah Lot berupa keindahan pantai dengan batu karang yang sangat unik, serta wisatawan juga bisa menyaksikan terbenamnya matahari (sunset). Wisatawan yang memberikan tanggapan sangat indah tentang pemadangan alam Tanah Lot adalah sebanyak 50 persen. Yang memberikan tanggapan indah sebanyak 28 persen. Sedangkan yang memberikan tanggapan cukup indah sebanyak 22 persen. Hasil ini menunjukkan bahwa mayoritas wisatawan yang memberikan tanggapan tentang pemandangan alam destinasi wisata Tanah 
Lot dikategorikan sangat indah, sesuai dengan apa yang dilihat dan dirasakan.

\subsection{Kebersihan Lingkungan Tanah Lot}

Kebersihan merupakan salah satu unsur yang sangat mempengaruhi dalam menciptakan kesan terhadap suatu tempat. Lingkungan yang bersih dan nyaman menjadikan wisatawan merasa betah untuk tinggal lebih lama. Wisatawan yang memberikan tanggapan sangat bersih sebanyak 20 persen, yang memberikan tanggapan bersih sebanyak 42 persen, dan yang memberikan tanggapan cukup bersih sebanyak 38 persen, dengan alasan masih ada coret-coret pada dinding atau tempat duduk Bale Bengong. Hal ini menunjukkan persepsi wisatawan tentang kebersihan lingkungan di sekitar Tanah Lot dikategorikan bersih.

\subsection{Tingkat Kepuasan Dalam Mengunjungi Tanah Lot}

Tujuan Wisatawan yang mengunjungi suatu DTW adalah untuk kepuasan diri sesuai dengan apa yang mereka butuhkan dan apa yang mereka inginkan. Apabila kebutuhan dan keinginan mereka terpenuhi maka mereka akan merasa puas dengan kegiatan perjalanan yang mereka lakukan. Persepsi wisatawan tentang tingkat kepuasan yang diperoleh di Tanah Lot yang menyatakan sangat puas adalah sebanyak 23 persen. Yang memberikan tanggapan puas sebanyak 40 persen. Sedangkan yang memberikan tanggapan cukup puas sebanyak 26 orang, dan yang memberikan tanggapan tidak puas sebanyak 11 persen dengan alasan belum terpenuhi kebutuhan dan keinginan yang mereka harapkan. Hal ini menunjukan persepsi wisatawan tentang tigkat kepuasan yang terdapat di Tanah Lot dikategorikan aman.

\subsection{Tingkat Pelayanan}

Pada tingkat pelayanan sangat dibutuhkan oleh wisatawan dalam mengunjungi suatu DTW. Dengan memberikan pelayanan yang baik terhadap wisatawan maka wisatawan akan merasa nyaman ketika berada 
di destinasi wisata tersebut sehingga wisatawan akan merasa puas dengan pelayanan yang diberikan oleh daerah tuan rumah. Wisatawan yang memberikan tanggapan sangat baik adalah sebanyak 19 persen, yang memberikan tanggapan baik 49 persen. Sedangkan yang memberikan tanggapan cukup baik sebanyak 32 persen, dengan alasan pelayanan yang diberikan sudah cukup baik akan tetapi masih terdapat pelayanan yang belum memuaskan. Hal ini menunjukkan bahwa pelayanan yang diberikan kepada wisatawan dikategorikan baik.

\subsection{Keamanan Di Tanah Lot}

Dalam mengunjungi suatu daerah destinasi wisata tentunya akan dilihat dari segi keamanannya. Jika di suatu Daerah Tujuan Wisata dalam keadaan aman maka tidak akan menjadi kendala bagi wisatawan untuk melakukan kunjungan wisata ke daerah tersebut. Persepsi wisatawan terhadap keamanan di sekitar Tanah Lot yang menyatakan sangat aman adalah sebanyak 27 persen. Yang memberikan tanggapan aman sebanyak 48 persen. Sedangkan yang memberikan tanggapan cukup aman sebanyak 24 persen. Hal ini menunjukan persepsi wisatawan tentang fasilitas yang terdapat di Tanah Lot dikategorikan aman.

\subsection{Amenities/Fasilitas Di Tanah Lot}

Sebuah daya tarik wisata disamping harus mempunyai dayat arik berupa keindahan dan keunikan juga harus menyediakan fasilitas yang diperlukan wisatawan. Keberadaan fasilitas penunjang turut membantu dalam mendukung pengembangan suatu daya tarik wisata. Wisatawan yang memberikan tanggapan sangat lengkap adalah sebanyak 19 persen, yang memberikan tanggapan lengkap 38 persen. Sedangkan yang memberikan tanggapan cukup lengkap sebanyak 42 persen, dengan alasan fasilitas yang tersedia sudah cukup membantu wisatawan dan akan menjadi lebih baik jika dikembangkan fasilitas pendukung lain. Dan yang memberikan tanggapan tidak lengkap sebanyak 1 persen, dengan alasan 
masih terdapat berbagai fasilitas yang perlu disediakan untuk melengkapi segala fasilitas yang dibutuhkan dan diinginkan wisatawan. Hal ini menunjukan persepsi wisatawan tentang fasilitas yang terdapat di Tanah Lot dikategorikan cukup lengkap.

\subsection{Akses Menuju Tanah Lot}

Salah satu hal yang perlu diperhatikan dalam kegiatan pariwisata adalah aksesibilitas yang merupakan hal penting bagi wisatawan untuk melakukan perjalanan wisata mulai dari daerah asalnya hingga Daerah Tujuan Wisata, dan merupakan jalan masuk atau pintu masuk utama ke DTW. Tanpa akses pariwisata, wisatawan tidak akan bisa melakukan perjalanannya. Wisatawan yang memberikan tanggapan sangat bagus adalah sebanyak 23 persen. Yang memberikan tanggapan bagus sebanyak 42 persen. Sedangkan yang memberikan tanggapan cukup bagus sebanyak 32 persen, dan wisatawan yang memberikan tanggapan tidak bagus sebanyak 3 persen, dengan alasan akses menuju Tanah Lot masih sempit dan ada juga jalan yang masih berlubang sehingga perlu untuk diperbaiki. Hal ini berarti, persepsi wisatawan tentang akses menuju Tanah Lot dikategorikan bagus.

\subsection{Kejenuhan Berkunjung Ke Tanah Lot}

Jika kita mengunjungi suatu destinasi wisata mungkin kita akan tertarik dan kembali mengunjungi daerah wisata tersebut secara berulang kali. Untuk itu perlu diketahui persepsi wisatawan tentang perasaan yang dirasakan saat mengunjungi sebuah destinasi wisata tentang apa yang dirasakan ketika berkunjung ke tempat yang sebelumnya sudah dikunjungi. Wisatawan yang merasa jenuh atau bosan saat mengunjungi Tanah Lot secara berulang kali adalah sebanyak 11 persen. Dengan alasan tidak ada perubahan tentang keadaan Tanah Lot sehingga perlu disediakan produk lain yang dapat menarik minat wisatawan. Dan wisatawan yang tidak jenuh atau bosan sebanyak 89 persen, dengan alasan keindahan alam 
yang eksotik di Tanah Lot sangat menarik sehingga mereka tidak pernah bosan untuk kembali berkunjung. Hal ini menunjukan bahwa persepsi wisatawan tentang perasaan yang dirasakan ketika berkunjung ke Tanah Lot kebanyakan wisatawan tidak merasa jenuh dalam mengunjungi destinasi wisata tersebut.

\subsection{Atraksi Budaya (Tari Kecak) Di Tanah Lot}

Dalam suatu DTW tentu memiliki atraksi-atraksi yang disediakan sebagai daya tarik wisata, selain atraksi alam, juga adanya atraksi buatan maupun atraksi budaya. Atraksi budaya yang disediakan di Tanah Lot seperti Tarik Kecak yang dipertunjukkan kepada para wisatawan sebagai hiburan. Oleh sebab itu, perlu adanya tanggapan dari wisatawan tentang atraksi budaya (Tari Kecak) yang dipentas, khususnya bagi wisatawan yang pernah menyaksikannya. Wisatawan yang tertarik menyaksikan atraksi budaya (Tari Kecak) adalah sebanyak 87 persen. Tari Kecak yang dipentaskan mampu menghibur para wisatawan dengan keaslian budaya yang dimiliki pulau Bali pada umumnya dan juga acara pentasnya bertepatan dengan terbenamnya matahari (sunset), suasana seperti inilah yang dapat menarik minat wisatawan untuk menyaksikan acara tersebut. Sedangkan wisatawan yang tidak tertarik meyaksikan atraksi budaya (Tari Kecak) sebanyak 13 persen. Hal ini menunjukkan bahwa persepsi wisatawan terhadap atraksi budaya (Tari Kecak) sebagian besar tertarik dengan atraksi budaya tersebut.

\section{PENUTUP}

Ditetapkannya Tanah Lot sebagai destinasi wisata unggulan karena keindahan alam dan keunikan budaya yang beraneka ragam, mampu menggalakkan wisatawan dari belahan dunia untuk mengunjungi destinasi ini. Dengan segala produk yang tersedia, mampu memenuhi permintaan dan penawaran atau kebutuhan dan keinginan wisatawan 
sehingga kepuasan akan berwisata dapat dinikmati oleh para wisatawan. Sesuai dengan persepsi wisatawan, menunjukkan bahwa mayoritas memberikan tanggapan yang positif terhadap keadaan dan keberadaan Tanah Lot, baik dari aspek Sumber Daya Alam, Sumber Daya Manusia, maupun Sumber Daya Sosial-Budaya.

Adapun saran yang diajukan untuk meningkatkan kualitas pelayanan kepada wisatawan, di antaranya adalah: (1) Pihak pengelola perlu memberikan penyuluhan dan pembinaan kepada para pedagang di destinasi wisata Tanah Lot tentang bagaimana memberikan pelayanan yang presisi kepada wisatawan, sebagaimana yang tertera dalam komentar dari wisatawan bahwa adanya paksaan dari pedagang acungb untuk membeli barang yang dijual. (2) Perlu dilengkapi berbagai fasilitasfasilitas yang belum tersedia seperti wertafel di toilet, dan pada tempat parkir perlu dibuat penutup atau atap untuk melindungi kendaraan dari panas terik matahari. (3) Perlu dikembangkan produk-produk wisata yang berbeda dengan lainnya agar wisatawan tidak merasa jenuh atau bosan dalam mengujungi destinasi wisata Tanah Lot.

\section{DAFTAR PUSTAKA}

Anonim, 2011. Data Jumlah Kunjungan Wisatawan Ke Provinsi Bali Tahun 2007-2011. Renon: DISPARDA Bali.

, 2011. Data Jumlah Kunjungan Wisatawan Ke Tanah Lot 20072011. Tanah Lot: Manajemen Operasional Tanah Lot.

Arikunto Suharsimi. 2002. Prosedur Penelitian Suatu Pendekatan Praktek. Edisi Revisi V. Jakarta: Rieneka Cipta.

Hasanudin Z. 2007. Konsep Dasar Pemetaan. Bandung: Kelompok Keilmian Geodesi. (http://www.google.konsepdasarpemetaan. pdf.)

Kusmayadi Sugiarto, Endar. 2000. Metodologi dalam Bidang Kepariwisataan. Jakarta: PT Gramedia Pustaka Utama.

Mill, Robert Christie. 2000. The Tourism International Business. Edisi Bahasa Indonesia. Jakarta: PT Raja Grafindo Persada. 
Muriawan, Agus. 2011. Analisis Pariwisata. Denpasar: Fakultas Pariwisata Universitas Udayana.

Pitana, I Gde. 2005. Sosiologi Pariwisata, Kajian Sosiologis Terhadap Struktur, Sistem, dan Dampak-Dampak Pariwisata. Yogyakarta: Andi Offset.

Pitana dan Diarta Surya. 2009. Pengantar Ilmu Pariwisata. Yogyakarta: Andi.

Pitana dan Gayatri. 2005. Sosiologi Pariwisata. Yogyakarta: Andi.

Ridwan. 2010. Dasar - Dasar Statistika. Bandung: Alfabeta.

Rudito B dan Famiola M. 2008. Social Maping-Metode Pemetaan Sosial. Bandung: Rekayasa Sains Bandung.

Sugiarta E dan Kusmayadi. 2000. Metodologi Penelitian dalam Bidang Kepariwisataan. Jakarta: PT Gramedia Pustaka Utama. Undang-Undang No. 10 Tahun 2010, Tentang Kepariwisataan.

\section{KUESIONER WISATAWAN DI DESTINASI WISATA TANAH LOT}

\section{Demografi}

1. Nama

2. Asal Wisatawan

3. Jenis Kelamin

$\square$ Laki-Laki

$\square$ Perempuan

4. Umur
$\square$ 15-25 Tahun
$\square$ 36-45 Tahun
$\square$ 26-35 Tahun
$\square 46$ Tahun ke atas

5. Pendidikan

$\begin{array}{ll}\square \text { SD } & \square \text { SMA/SMK } \\ \square \text { SMP } & \square \text { Serjana }\end{array}$

6. Pekerjaan

7. Berapa Kali Berkunjung:

\section{Mohon Diisi Dan Berikan Informasi}

1. Bagaimana persepsi Anda tentang pemandangan alam di Tanah Lot?
$\square$ Sangat indah
$\square$ Tidak Indah
$\square$ Indah
$\square$ Sangat Tidak Indah
$\square$ Cukup Indah

2. Bagaimana persepsi Anda tentang kebersihan di lingkungan sekitar Tanah Lot?
$\square$ Sangat Bersih
$\square$ Kurang Bersih
$\square$ Bersih
$\square$ Sangat Tidak Bersih
$\square$ Cukup Bersih 
3. Bagaimana persepsi Anda tentang tingkat kepuasan dalam mengunjungi Tanah Lot?
$\square$ Sangat Puas
$\square$ Kurang Puas
$\square$ Puas
$\square$ Sangat Tidak Puas
$\square$ Cukup Puas

4. Bagaimana persepsi Anda tentang tingkat pelayanan yang terdapat di Tanah Lot?
$\square$ Sangat Baik
$\square$ Tidak Baik
$\square$ Baik
$\square$ Sangat Tidak Baik
$\square$ Cukup Baik

5. Bagaimana persepsi Anda tentang area parkir di sekitar Tanah Lot?
$\square$ Sangat teratur
$\square$ Tidak Teratur
$\square$ Teratur
$\square$ Sangat tidak teratur

$\square$ Cukup Teratur

6. Bagaimana persepsi Anda tentang keamanan yang ada di Tanah Lot?
$\square$ Sangat Aman
$\square$ Tidak Aman
$\square$ Aman
$\square$ Sangat Tidak Aman
$\square$ Cukup Aman

7. Bagaimana persepsi Anda tentang amenities (fasilitas) yang ada di tanah Lot?
$\square$ Sangat Lengkap
$\square$ Tidak Lengkap
$\square$ Lengkap
$\square$ Cukup Lengkap
$\square$ Sangat Tidak Lengkap

8. Bagaimana persepsi anda tentang akses menuju Tanah Lot?
$\square$ Sangat Bagus
$\square$ Tidak Bagus
$\square$ Bagus
$\square$ Sangat Tidak Bagus
$\square$ Cukup Bagus

9. Jika Anda pernah mengunjungi Tanah Lot sebelumnya, apakah Anda merasa jenuh/bosan saat berkunjung ke Tanah Lot?
$\square \mathrm{Ya}$
$\square$ Tidak

10. Apakah Anda tertarik menyaksikan atraksi Budaya seperti Tari Kecak (Jika anda pernah menyaksikan) yang ada di Tanah Lot?

$\square$ Tertarik $\quad \square$ Tidak Tertarik

Aktivitas apa yang Anda lakukan di Tanah Lot?

Apa yang memotivasi Anda untuk berkunjung ke Tanah Lot? 
Syul Rosli Sanam 